\title{
TIEDON ÄÄNI - PÄÄTÖKSENTEON TIETOTUKIHANKE LUO POHJAA TULEVILLE PALVELUILLE
}

Kansanedustajissa on 200 erilaista tapaa hankkia ja käyttää tietoa, ja tietopalvelun on tarjottava heille kaikille jotakin. Eduskunnan kirjaston päätöksenteon tietotukihankkeessa etsitään uudenlaisia tapoja tuottaa palveluita. Hankkeessa on selvitetty, miten kirjaston ja tietopalvelun nykyinen toiminta tukee eduskuntatyötä ja millaisia palveluita ulkomailta löytyy. Artikkelissa käydään läpi eduskuntaan liittyvän tiedonhankinnan erityispiirteitä ja tiedon käyttöä päätöksenteon prosessissa.

$\mathrm{T}$ ietoon perustuva päätöksenteko on päivän sana. Ajattelumallin tavoitteena on saattaa perustelut, tieto, tiede ja tieteellinen prosessi osaksi päätöksentekoa. Kuulostaa sinänsä äärimmäisen järkevältä, koska tutkittua tietoa on jatkuvasti enemmän ja enemmän saatavilla ja se on koko ajan laadukkaampaa. Tämä on tieteellisen prosessin itsekorjautuvuuden ajatus vanha tieto korjautuu jatkuvasti uudella, tarkemmalla, perustellummalla ja arvioidummalla tiedolla. Koko ajan päästään lähemmäs lopullista totuutta, mikä se ikinä onkaan.

Oleellinen kysymys on, miten päättäjä ja paras mahdollinen tieto kohtaisivat oikea-aikaisesti ja miten tutkittu tieto saataisiin mahdollisimman luontevasti osaksi poliittista prosessia.

\section{Päätöksenteon tietotukihanke}

duskunnan kansliassa toimivat Eduskunnan kirjasto ja Eduskunnan sisäinen tietopalvelu ovat ne tahot, jotka tuottavat eduskunnalle tietotukipalveluita. Työnja- ko on karkeasti ottaen se, että kirjasto hoitaa aineistopalvelut ja sisäinen tietopalvelu tekee toimeksiannosta analyyseja, selvityksiä ja laskelmia. On koko ajan haastavampaa pysyä kärryillä siitä, minkälainen tieto olisi tarpeen, missä vaiheessa ja missä muodossa, jotta siitä olisi päätöksenteon kannalta relevanssia.

Päätöksenteon tietotukihankkeessa kartoitetaan nykyisten palveluiden tilanne, hankitaan vertailuaineistoa Suomesta ja ulkomailta ja etsitään uudenlaisia tapoja tuottaa tietotukea. Hankkeessa tukena on Sitra, joka samanaikaisesti tukee eduskuntaa myös laajemmassa eduskuntatyön kehittämishankkeessa, jossa pohditaan muun muassa valiokuntatyön sujuvoittamista.

Tietotukihankkeen kartoitusvaiheessa selvitettiin kirjaston ja tietopalvelun tarjoamat palvelut eduskunnalle, niiden käyttövolyymit ja niihin käytettävät resurssit. Vertailutietoa haettiin ensisijassa muista Pohjoismaista mutta myös muualta Euroopasta käyttäen
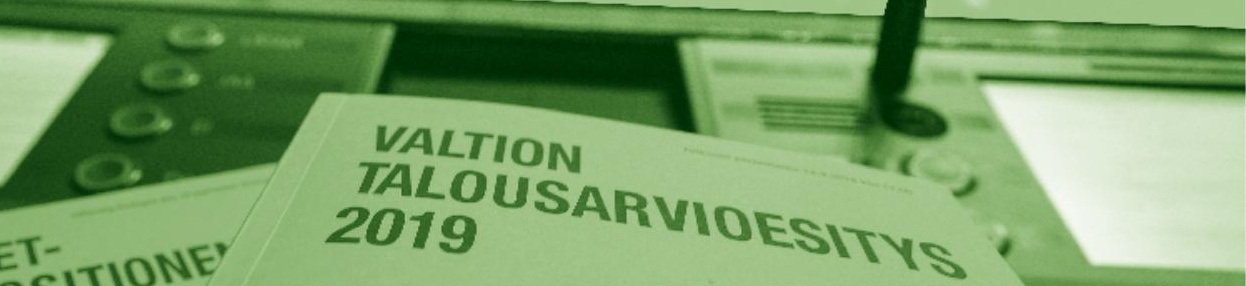
hyväksi eurooppalaisten parlamenttien ECPRD-verkostoa. Yleisesti voi todeta, että muualla tuotetaan varsin samanlaisia palveluita, mutta kunkin maan koko, resurssit ja poliittinen järjestelmä näkyvät myös tiettyinä eroavaisuuksina. Jonkin verran on saatu tietoa palvelumalleista, joita voisi soveltaen hyödyntää myös Suomessa. Erityisesti verrokkimaissa tuotettavat proaktiiviset tietotuotteet kuten erilaiset tilastoseurantapalvelut tai embedded librarianship -yhteistyömallit ovat kiinnostavia.

Esiselvitysvaiheessa pyrittiin selvittämään, miten kirjaston ja tietopalvelun nykyiset palvelut tukevat eduskuntatyötä ja miten niitä käytetään. Eduskunnalle suunnatuissa palvelukyselyissä saamme aina erinomaiset tulokset ja palautekin on yleensä kiittävää, mutta kovinkaan syvällistä tietoa palveluiden käytöstä ei ole.

\section{Kansanedustajan tiedontarpeet}

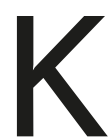

eskeinen tiedon käyttäjien ryhmä eduskunnassa ovat tietenkin kansanedustajat itse. Kansanedustajissa on 200 erilaista tapaa hankkia ja käyttää tietoa. Useimmat heistä toimivat laaja-alaisesti politiikan eri osa-alueilla, mikä saa poliitikot arvostamaan tiivistelmiä, muistioita ja tehokasta tiedonhankintaa. Poliitikoissa on myös tietylle sektorille suuntautuneita asiantuntijoita sekä tutkijataustaisia poliitikkoja, joista erityisesti jälkimmäiset käyttävät kirjaston palveluita ahkerasti. Kaikkia kansanedustajia yhdistää kuitenkin alati pahentuva aikapula ja toisaalta tietotulva. Tiedon- hankintaan ja käyttöön liittyvä ajanpuute on keskeinen vaikutin siihen, miksi tietotukipalveluita on kehitettävä ja tietoa asiakkaiden tarpeista on saatava yhä tehokkaammin.

Hankkeen kannalta olennainen kysymys on, missä ja miten tietoa käytetään ja miten se liittyy päätöksenteon prosessiin. Poliittisen päätöksenteon ja lainsäädäntötyön kannalta keskeinen tiedonkäyttöprosessi on hallitusneuvottelut ja hallitusohjelman laadinta. Vaalikauden aikana tehtävät päätökset pohjautuvat hallitusohjelmaan, joten Säätytalolla tapahtuva tiedonkäyttö on todellinen solmukohta lainsäädäntöprosessin kannalta. Se, että paikalle marssitetaan huippuasiantuntijoita, vaikuttajaviestijöitä ja kokeneita poliitikoita, kertoo massiivisesta tiedonkäyttöoperaatiosta. Millainen Graalin malja tiedonkäytön tutkijoille olisikaan päästä seuraamaan ja analysoimaan hallitusneuvotteluiden tiedonkäyttöä!

Hallituksen- ja hallitusohjelman muodostumisen jälkeen käynnistyy lainsäädäntötyö. Lakeja valmistellaan ministeriöissä, joissa alan asiantuntijat hankkivat ja käyttävät saatavissa olevaa tutkimustietoa parhaan taitonsa mukaan. Lainvalmistelun haasteista on viime vuosina puhuttu paljon julkisuudessa ja näissä keskusteluissa puhutaan loppujen lopuksi aika usein ajasta tai sen puutteesta. Lakipaketit ovat usein laajoja ja monimutkaisia, minkä lisäksi prosessi edellyttää monenlaisen taustoittavan ja vertailevan aineiston käyttöä. Ja samaan aikaan aikataulut ovat tiukkoja ja usein muuttuvia.

Kun lakiesitys aikanaan saapuu 
eduskunnan käsittelyyn, sen käsittely ohjataan lain sisällön mukaan erikoisvaliokuntaan. Valiokuntien keskeinen tiedonhankintatapa on asiantuntijoiden kuuleminen. Tässä prosessissa parasta mahdollista tutkimustietoa hyödyntävä asiantuntija tarjoaa näkemyksensä päättäjille, jotka tekevät eri näkökulmia yhdistellen lakiesityksestä mietinnön. Päätöksenteon tietotukihankkeen kannalta relevantti kysymys on, miten tietotukipalvelut parhaiten voisivat tukea valiokuntien työtä tässä vaiheessa.

\section{Virkamiehet ja avustajat tietotyön tukena}

Kansanedustajilla on lainsäädäntötyön lisäksi koko joukko muitakin rooleja, joihin kaikkiin liittyy erilaisia tiedontarpeita. Edustajat ovat jatkuvasti kontaktissa kansalaisiin, joilla on monenlaisia huolia ja kysymyksiä yhteiskunnan kaikilta osa-alueilta. Toisaalta he toimivat oman viiteryhmänsä poliittisten linjausten ja politiikkaohjelmien valmistelijoina. Lisäksi edustajilla on kansainvälisiä velvoitteita, jotka vaativat syvällistä perehtymistä monenlaisiin aiheisiin ja alueisiin.

Kansanedustajien työn tukena ovat eduskunnan kanslian virkamiehet ja eduskunta-avustajat. Esimerkiksi valiokuntien ja eduskuntaryhmien henkilöstöt ovat keskeisiä tiedonkäyttäjiä eduskunnassa ja ovat näin osa sitä asiantuntijoiden tietotukikoneistoa, joka on kansanedustajan työn tukena. Avustajajärjestelmässä on lisäksi tapahtunut viime vuosina merkittävä muutos henkilökohtaisten avustajien korvau- tuessa yhä useammin ryhmäkanslioilla. Avustajat toimivat ryhmäkanslioissa omaan alaansa erikoistuneena asiantuntijana. On oletettavaa, että samalla myös tiedonkäyttö on systematisoitunut ja tehostunut.

Eduskuntatyö on kansanedustajalle mitä suurimmassa määrin tietotyötä. On kuitenkin hyvä muistaa, että kyse on politiikasta, arvoista ja kansan edustamisesta. Joskus voi olla tilanteita, joissa on käytettävissä toisistaan hyvin poikkeavia sinänsä tieteellisesti todistettuja faktoja, jolloin päättäjän on joka tapauksessa luotettava viime kädessä omaan arvopohjaansa ja arvioonsa.

\section{Entä sitten?}

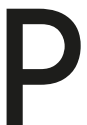

äätöksenteon tietotukihanke on siinä vaiheessa, että taustatyö on tehty. Seuraavaksi edetään kokeilemaan eli päätetään jatkohankkeista. Minkälaisia uusia palvelumalleja? Mitä uusia sisältöpalveluita? Mitä uusia aineistoja? On melko selvää, että tulevaisuus on entistä digitaalisempi, räätälöidympi ja oikea-aikaisempi. Osaajia tullaan tarvitsemaan. Silloin ei riitä, että haetaan kirjastoon digiosaajaa kehittämään tulevaisuuden verkkopalveluita.

Joidenkin vuosien kuluttua voimme arvioida, miten olemme vastanneet haasteeseen. Onko tieto lisääntynyt päätöksenteossa? Kokevatko päättäjät pääsevänsä helpommin relevantin tiedon ääreen? Kuuluuko tiedon ääni paremmin? Nyt ollaan taitekohdassa.

\section{Kirjoittaja}

ANTTI VirRanKoski

Eduskunnan kirjasto

antti.virrankoski@eduskunta.fi 